\title{
Development of Particle Swarm Optimization and Simulated Annealing Algorithms to Solve Vehicle Routing Problems With Drones
}

\section{Pengembangan Algoritma Particle Swarm Optimization dan Simulated Annealing untuk Menyelesaikan Vehicle Routing Problem with Drone}

\author{
Hasan Aji Prawira ${ }^{1}$, Budi Santosa ${ }^{2}$. \\ Departemen Teknik Industri, Institut Teknologi Sepuluh Nopember \\ E-mail: hasanajip97@gmail.com¹․ budi_s@ie.its.ac.id ${ }^{2}$
}

\begin{abstract}
Vehicle Routing Problem with Drone (VRPD) is a problem of determining the number of routes for delivery of goods from the depot to a number of customers using trucks and drones. Drones are an alternative delivery tool besides trucks, each truck can be equipped with a support drone. Drones can be used to make a delivery while the truck is making others. By combining a truck and a drone, the truck can act as a tool for drone launch and landing so that the drones can reach long distances from the depot. The purpose of this problem is to minimize the cost of sending goods by trucks and drones. In this study, the Particle Swarm Optimization (PSO) and the Simulated Annealing (SA) are proposed to solve these problems. The Route Drone algorithm are used to help change the structure of the PSO and SA solutions into a VRPD solution. The proposed algorithm has been applied to 24 different scenarios ranging from 6 customers to 100 customers. The PSO and SA algorithms are able to find solutions that are close to optimal. The SA is able to find a better solution than the PSO.
\end{abstract}

Keywords: Vehicle Routing Problem, Drone, Particle Swarm Optimization, Simulated Annealing, Metaheuristic, Vehicle Routing Problem with Drone.

\begin{abstract}
ABSTRAK
Vehicle Routing Problem with Drone (VRPD) merupakan permasalahan penentuan sejumlah rute pengiriman barang dari depo ke sejumlah kostumer dengan menggunakan truk dan drone. Drone menjadi alternatif alat pengiriman selain truk, setiap truk dapat dilengkapi dengan drone pendukung. Drone dapat digunakan untuk melakukan beberapa pengiriman saat truk melakukan pengiriman yang lain. Dengan mengkombinasikan truk dan drone, truk dapat berperan sebagai alat untuk peluncuran dan pendaratan drone sehingga drone dapat mencapai jarak yang jauh dari depot. Tujuan permasalahan ini adalah meminimasi biaya pengiriman barang oleh truk dan drone. Dalam penelitian ini, diusulkan algoritma Particle Swarm Optimization (PSO) dan algoritma Simulated Annealing (SA) untuk menyelesaikan permasalahan tersebut. Algoritma Route Drone digunakan untuk membantu mengubah struktur solusi algoritma PSO dan SA menjadi solusi VRPD. Algoritma yang diusulkan telah diaplikasikan untuk 24 macam skenario mulai dari 6 pelanggan hingga 100 pelanggan. Algoritma PSO dan SA mampu menemukan solusi yang mendekati optimal. Algoritma SA mampu menemukan solusi yang lebih baik dibandingkan algoritma PSO.
\end{abstract}

Kata kunci: Vehicle Routing Problem, Drone, Particle Swarm Optimization, Simulated Annealing, Metaheuristik, Vehicle Routing Problem with Drone.

\section{PENDAHULUAN}

Pengiriman barang ke end costumer atau biasa disebut last mile delivery merupakan salah satu proses penting dalam sistem logistik. Adanya persaingan yang tinggi di pasar mengakibatkan pelanggan cenderung membeli layanan dan produk dari perusahaan dengan pengiriman yang cepat, fleksibel, dan murah. Oleh karena itu, perusahaan-perusahaan yang bergerak di bidang logistik selalu mencari cara untuk mempercepat dan mengefisienkan biaya pada last mile delivery. Salah satu cara yang menjadi perhatian belum lama ini adalah Pengembangan Algoritma Particle Swarm Optimization dan Simulated Annealiang untuk Menyelesaikan Vehicle Routing Problem with Drone / Hasan Aji Prawira, Budi Santosa

Peer reviewed under responsibili of Universitas Muhammadiyah Sidoarjo.

(C) 2021 Universitas Muhammadiyah Sidoarjo. All Right reserved. This is an open access article under the CC BY licence (http://creativecommons.org/licences/by/4.0/ ) 


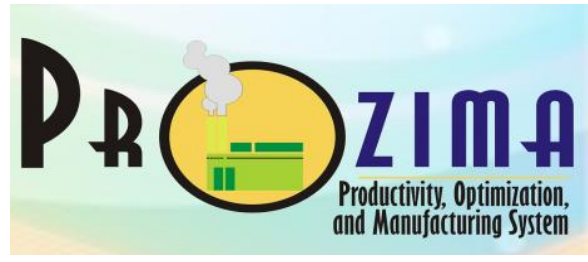

Prozima, Vol. 5, No. 1, Juni 2021, 1-12

E. ISSN. 2541-5115

Journal Homepage: http://ojs.umsida.ac.id/index.php/prozima

DOI Link: http://doi.org/ 10.21070/prozima.v5i1.1398

Article DOI: http://doi.org/ 10.21070/prozima.v5i1.1398

penggunaan Unmanned Aerial Vehicles (UAVs) atau sering disebut drone untuk pengiriman barang ke lokasi pelanggan [1]. Drone memiliki beberapa keunggulan dibandingkan dengan truk dalam melakukan pengiriman barang yaitu dapat menghindari kemacetan sehingga lebih cepat dalam pengiriman, biaya per kilometer yang lebih murah [2] dan pengoperasian tanpa biaya pengemudi. Pengiriman barang menggunakan drone menjadi pusat perhatian, saat Jeff Bezos, CEO Amazon, mengumumkan bahwa perusahaannya sedang mengembangkan gagasan penggunaan drone untuk pengiriman komoditas kecil [3]. Amazon tidak sendirian dalam pengembangan pengiriman menggunakan drone. Grup pos dan logistik Jerman Deutsche Post DHL baru-baru ini mengumumkan bahwa Parcelcopter mereka telah diberi wewenang untuk mengirimkan pasokan medis ke pulau bebas mobil di lepas pantai Jerman [4]. Perusahaan JD juga telah melakukan percobaan pengirimian menggunakan drone di Indonesia [5].

Bedasarkan paparan diatas, drone telah dianggap sebagai pilihan yang menjanjikan untuk aplikasi industri logistik. Tetapi, drone tidak bisa dianggap sebagai alternatif pengganti kendaraan pengiriman konvensional seperti truk melainkan sebagai alat pengiriman yang saling melengkapi. Hal ini disebabkan drone memiliki keterbatasan pada kapasitas muatan dan jarak terbang dibandingkan truk. Jika dibandingkan dengan drone, truk dapat membawa barang yang lebih berat dan menempuh jarak yang jauh. Tanpa adanya truk, drone tidak bisa memenuhi semua permintaan pengiriman. Pengiriman dengan mengkombinasikan truk dan drone menjadi cara yang efisien karena dapat memanfaatkan masing-masing keunggulannya. Penggunaan truk dan drone memungkinkan pengiriman lebih cepat karena truk dan drone dapat mengirimkan barang secara simultan tanpa adanya tambahan jarak [6]. Bedasarkan literatur, permasalahan pengiriman barang-barang kecil dengan banyak titik pelanggan sering diformulasikan sebagai Vehicle Routing Problem (VRP) [7]. Setelah adanya drone sebagai alternatif alat pengiriman, setiap truk dapat dilengkapi dengan drone pendukung. Drone dapat digunakan untuk melakukan beberapa pengiriman saat truk melakukan pengiriman yang lain. Dengan mengkombinasikan truk dan drone, truk dapat berperan sebagai alat untuk peluncuran dan pendaratan drone sehingga drone dapat mencapai jarak yang jauh dari depot. Pemodelan permasalahan ini sering disebut Vehicle Routing Problem with Drone (VRP-D) [8].

Penelitian pertama yang mempelajari kerja sama antara truk dan drone dilakukan oleh [9] dengan menggunakan Traveling Salesman Problem (TSP) sebagai model dasar. [9] Muray menyebut permasalahan tersebut sebagai Flying Sidekick Traveling Salesman Problem (FSTSP). Permasalahan tersebut adalah varian dari TSP yang hanya menggunakan satu truk dengan satu drone untuk mengirimkan barang ke pelanggan. Drone diterbangkan dari suatu lokasi untuk mengirimkan barang ke pelanggan dan mendarat di lokasi pertemuan dengan truk. Saat drone terbang, truk dapat mengunjungi pelanggan lain, namun truk harus sampai di lokasi pertemuan sebelum baterai drone habis. Dalam permasalahan ini, fungsi tujuannya adalah meminimalkan waktu penyelesaian rute. Studi terbaru, seperti [9], [10], [11], [12], [13], dan [8] telah menyelidiki keuntungan penggunaan kedua kendaraan ini dibandingkan dengan mendistribusikan barang hanya menggunakan truk.

Penelitian ini berfokus pada VRP-D dengan setiap truk dilengkapi satu drone pendukung. Permasalahan VRP-D merupakan permasalahan berklasifikasi NP-hard sehingga metode exact memerlukan waktu yang sangat lama untuk menemukan solusi yang optimal. VRP-D bisa diselesaikan dengan menggunakan metode exact jika skala permasalahan kecil atau sekitar 10-20 titik pelanggan [12]. Sedangkan, VRP-D perlu penyelesaian yang cepat karena frekuensi pengiriman yang besar. Oleh karena itu, pengembangan metode heuristik untuk menyelesaikan VRP-D dengan skala permasalahan besar lebih diutamakan dibandingkan metode exact. Penelitian ini menggunakan metode metaheuristik untuk menyelesaikan VRP-D. Pendekatan metaheuristik dipilih karena metaheuristik merupakan kelanjutan dari heuristik muncul sebagai alternatif pemecahan masalah-masalah yang sulit diselesaikan menggunakan metode exact [14]. Pada penelitian ini algoritma metaheuristik Particle Swarm Optimization (PSO) dan Simulated Annealing (SA) dipilih untuk menyelesaikan VRP-D. Kedua algoritma ini dipilih karena bedasarkan referensi terkait VRP-D, kedua algoritma ini belum pernah digunakan untuk menyelesaikan VRP-D. Selain itu, kedua algoritma ini merupakan algoritma yang sangat sering digunakan dan telah berhasil menyelesaikan permasalahan kontinyu dengan constraint[15], integer programming, serta

Pengembangan Algoritma Particle Swarm Optimization dan Simulated Annealiang untuk Menyelesaikan Vehicle Routing Problem with Drone / Hasan Aji Prawira, Budi Santosa

Peer reviewed under responsibili of Universitas Muhammadiyah Sidoarjo.

(C) 2021 Universitas Muhammadiyah Sidoarjo. All Right reserved. This is an open access article

under the CC BY licence (http://creativecommons.org/licences/by/4.0/ ) 


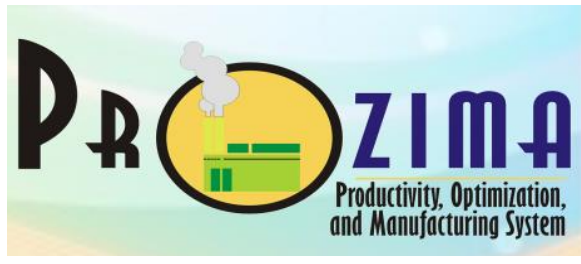

Prozima, Vol. 5, No. 1, Juni 2021, 1-12

E. ISSN. 2541-5115

Journal Homepage: http://ojs.umsida.ac.id/index.php/prozima

DOI Link: http://doi.org/ 10.21070/prozima.v5i1.1398

Article DOI: http://doi.org/ 10.21070/prozima.v5i1.1398

permasalahan combinatorial[16]. Pada penelitian ini kedua algoritma akan dibandingkan untuk mendapatkan algoritma yang menghasilkan solusi yang lebih baik.

\section{METODE}

\section{A. Model Matematis}

Vehicle Routing Problem with Drone (VRPD) merupakan salah satu jenis VRP yang tujuannya adalah untuk menentukan serangkaian rute optimal yang dilakukan oleh truk dan drone untuk melayani sejumlah pelanggan dengan beberapa kondisi yang harus terpenuhi [17]. Bedasarkan penelitian [8], formulasi matematika untuk VRPD dapat definisikan sebagai berikut. Himpunan-himpunan yang akan digunakan untuk memformulasikan permasalahan adalah sebagai berikut. $C$ merupakan himpunan titik pelanggan. $C^{\prime}$ merupakan himpunan bagian dari pelanggan yang dapat dilayani oleh drone. $D$ merupakan titik depot yang menunjukan awal dan akhir rute. $N$ merupakan himpunan semua titik. $N_{0}$ merupakan himpunan titik yang dapat digunakan untuk keberangkatan kendaraan. $N_{+}$merupakan himpunan titik yang dapat digunakan untuk kedatangan kendaraan. $\Delta^{+}(i)$ merupakan himpunan titik yang dapat dicapai dari titik $i$ yang merupakan elemen himpunan $N_{0}$. $\Delta^{-}(i)$ merupakan himpunan titik yang dapat digunakan untuk mencapai titik $i$ yang merupakan elemen himpunan $N_{+}$. $A$ merupakan himpunan feasible arc. $V$ merupakan himpunan truk homogen dengan $m$ adalah jumlah truk yang tersedia.

Parameter-parameter yang digunakan untuk formulasi matematika adalah sebagai berikut. $\tau_{i j}^{T}$ adalah waktu perjalanan truk dari $i \in N_{0}$ ke $j \in N_{+} \cdot \tau_{i j}^{D}$ adalah waktu perjalanan drone dari $i \in N_{0}$ ke $j \in N_{+}$. $c_{i j}^{T}$ adalah biaya perjalanan truk dari $i \in N_{0}$ ke $j \in N_{+}$. $c_{i j}^{D}$ adalah biaya perjalanan drone dari $i \in N_{0}$ ke $j \in N_{+}$. $Q$ adalah kapasitas truk. $q_{i}$ adalah demand pelanggan $i \in C$. $e$ adalah batas waktu terbang drone. $S e_{i}^{T}$ adalah waktu pelayanan truk di pelanggan $i \in C$. $S e_{i}^{D}$ adalah waktu pelayanan drone di pelanggan $i \in C^{\prime} . S L$ adalah waktu yang diperlukan untuk menerbangkan drone. $S R$ adalah waktu yang diperlukan untuk mendaratkan drone. $M$ adalah bilangan yang cukup besar. $T_{\max }$ adalah durasi maksimum setiap rute.

Selanjutnya, notasi tambahan diperlukan untuk mengidentifikasi kemungkinan sorties tiga titik dari drone. Didefinisikan $P$ adalah himpunan sorties yang mungkin, direpresentasikan dengan tuple $\langle i, j, k\rangle$. Titik pertama mewakili lokasi peluncuran drone, titik kedua mewakili pelanggan yang dikunjungi oleh drone, dan titik ketiga mewakili lokasi pendaratan drone. Oleh karena itu, elemen $\langle i, j, k\rangle$ milik himpunan $P$ berlaku kondisi berikut. Pertama, titik peluncuran $i \in N_{0}$ dari tuple adalah lokasi yang dapat digunakan untuk peluncuran drone sesuai dengan lokasi yang dapat digunakan untuk pemberangkatan truk. Kedua, titik pengiriman $j \in\left\{C^{\prime}: j \neq i\right\}$ dari tuple adalah himpunan pelanggan yang dapat dilayani oleh drone dan berbeda dengan posisi peluncuran $i$. Ketiga, titik pertemuan atau posisi pemulihan $k \in\left\{N_{+}: k \neq i, k \neq j, S L+S R+\tau_{i j}^{D}+\tau_{j k}^{D}+S e_{j}^{D} \leq e\right\}$ dari tuple adalah lokasi pertemuan drone dengan truk untuk pemulihan baterai drone.

Selanjutnya, tuple $\langle 0, i, c+1\rangle$ dihilangkan dari $P$ untuk semua $i \in C^{\prime}$. Tuple tersebut menunjukan pengiriman dengan drone dengan titik peluncuran dan pertemuan di depot. Biaya sortie $c_{s}^{D}$ dari sortie $s=\langle i, j, k\rangle$ dihitung dari $c_{s}^{D}=c_{i j}^{D}+c_{j k}^{D}$. Semua sortie dari $P$ dengan titik peluncuran $i \in N_{0}$ didefinisikan dengan notasi $P_{i}^{+}$. Semua sortie dari $P$ dengan titik pemulihan $k \in N_{+}$didefinisikan dengan notasi $P_{k}^{-}$dan $P_{j}$ adalah semua sortie dari $P$ yang mengirim ke pelanggan $j \in C^{\prime}$. Variabel keputusan yang digunakan untuk formulasi matematika adalah sebagai berikut. $x_{i j}^{v}$ adalah variabel biner yang bernilai 1 jika truk $v \in V$ melalui titik $i \in N_{0}$ dan $j \in N_{+}$. $u_{i}^{v}$ adalah variabel kontinyu yang menunjukan posisi kunjungan $i \in N$ pada rute truk $v \in V . t_{i}^{v}$ adalah variabel kontinyu yang menunjukan waktu dari rute truk $v \in V$ saat tiba di lokasi $i \in N . t_{i}^{\prime v}$ adalah variabel kontinyu yang menunjukan waktu drone dari truk $v \in V$ saat tiba di lokasi $i \in N$. $p_{i j}^{v}$ adalah variabel biner yang bernilai 1

Pengembangan Algoritma Particle Swarm Optimization dan Simulated Annealiang untuk Menyelesaikan Vehicle Routing Problem with Drone / Hasan Aji Prawira, Budi Santosa

Peer reviewed under responsibili of Universitas Muhammadiyah Sidoarjo.

(C) 2021 Universitas Muhammadiyah Sidoarjo. All Right reserved. This is an open access article

under the CC BY licence (http://creativecommons.org/licences/by/4.0/ ) 


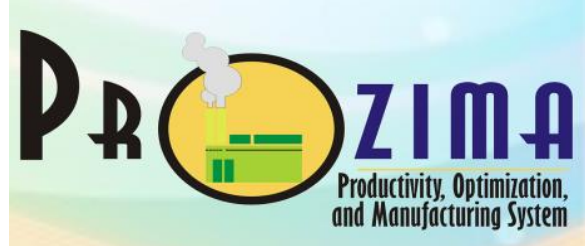

Prozima, Vol. 5, No. 1, Juni 2021, 1-12

E. ISSN. 2541-5115

Journal Homepage: http://ojs.umsida.ac.id/index.php/prozima

DOI Link: http://doi.org/ 10.21070/prozima.v5i1.1398

Article DOI: http://doi.org/ 10.21070/prozima.v5i1.1398

jika pelanggan $j \in C$ dikunjungi setelah lokasi $j \in N_{0}$ pada rute truk $v \in V . y_{s}^{v}$ adalah variabel biner yang bernilai 1 jika sortie $s \in P$ digunakan pada rute truk $v \in V$.

Bedasarkan himpunan, parameter dan variabel keputusan diatas, permasalahan VRPD dapat diformulasikan sebagai berikut.

Minimize

$$
\sum_{v \in V}\left(\sum_{(i, j) \in A} c_{i j}^{T} x_{i j}^{v}+\sum_{s \in P} c_{s}^{D} y_{s}^{v}\right)
$$

Subject to:

$$
\begin{aligned}
& \sum_{v \in V} \sum_{i \in \Delta^{-}(j)} x_{i j}^{v}+\sum_{v \in V} \sum_{s \in P_{j}} y_{s}^{v}=1 \\
& \forall j \in C \\
& \sum_{j \in N_{+}} x_{0, j}^{v} \leq 1 \\
& \sum_{i \in N_{0}} x_{i, c+1}^{v} \leq 1 \\
& \forall v \in V \\
& \forall v \in V \\
& x_{0, c+1}^{v}=0 \\
& \forall v \in V \\
& \sum_{i \in \Delta^{-}(j)} x_{i j}^{v}=\sum_{k \in \Delta^{+}(j)} x_{j k}^{v} \\
& \forall v \in V, j \in C \\
& u_{i}^{v}+1 \leq u_{j}^{v}+M\left(1-x_{i j}^{v}\right) \\
& \forall v \in V,(i, j) \in A \\
& u_{j}^{v} \leq M \sum_{i \in \Delta^{-}(j)} x_{i j}^{v} \\
& \forall v \in V, j \in N_{+} \\
& \sum_{j \in C}\left(\sum_{k \in \Delta^{+}(j)} q_{j} x_{j k}^{v}+\sum_{s \in P_{j}} q_{j} y_{s}^{v}\right) \leq Q \\
& \forall v \in V \\
& \sum_{s \in P_{i}^{+}} y_{s}^{v} \leq 1 \\
& \forall v \in V, i \in N_{0} \\
& \sum_{s \in P_{k}^{-}} y_{s}^{v} \leq 1 \\
& \forall v \in V, k \in N_{+} \\
& 2 y_{s}^{v} \leq \sum_{h \in \Delta^{+}(i)} x_{i h}^{v}+\sum_{l \in \Delta^{-}(k)} x_{l k}^{v} \\
& \forall v \in V, s=\langle i, j, k\rangle \in P \\
& t_{0}^{v}=0 \\
& \forall v \in V \\
& t_{0}^{\prime v}=0 \\
& \forall v \in V \\
& t_{c+1}^{v} \leq T_{\max } \sum_{i \in N_{0}} x_{i, c+1}^{v} \\
& \forall v \in V \\
& t_{c+1}^{\prime v} \leq T_{\max } \sum_{s \in P_{c+1}^{-}} y_{s}^{v} \\
& \forall v \in V \\
& t_{h}^{v}+\tau_{h k}^{T}+S e_{h}^{T}+S L \sum_{s \in P_{h}^{+}} y_{s}^{v}+S R \sum_{s \in P_{k}^{-}} y_{s}^{v} \leq t_{k}^{v}+T_{\max }\left(1-x_{h k}^{v}\right) \quad \forall v \in V,(h, k) \in A \\
& t_{i}^{v}+\tau_{h k}^{D}+S L-T_{\max }\left(1-\sum_{s \in P_{i}^{+} \cap P_{j}} y_{s}^{v}\right) \leq t_{j}^{v} \\
& \forall v \in V,(i, j) \in A
\end{aligned}
$$

Pengembangan Algoritma Particle Swarm Optimization dan Simulated Annealiang untuk Menyelesaikan Vehicle Routing Problem with Drone / Hasan Aji Prawira, Budi Santosa

Peer reviewed under responsibili of Universitas Muhammadiyah Sidoarjo.

(C) 2021 Universitas Muhammadiyah Sidoarjo. All Right reserved. This is an open access article under the CC BY licence (http://creativecommons.org/licences/by/4.0/ ) 


$$
\begin{array}{ll}
t_{j}^{\prime v}+\tau_{j k}^{D}+S e_{j}^{D}+S R-T_{\max }\left(1-\sum_{s \in P_{j} \cap P_{k}^{-}} y_{s}^{v}\right) \leq t_{k}^{\prime v} & \forall v \in V, j \in C^{\prime}, k \in \Delta^{+}(j) \\
t_{i}^{v}-T_{\max }\left(1-\sum_{s \in P_{i}^{+}} y_{s}^{v}\right) \leq t_{i}^{\prime v} & \forall v \in V, i \in N_{0} \\
t_{i}^{v}+T_{\max }\left(1-\sum_{s \in P_{i}^{+}} y_{s}^{v}\right) \geq t_{i}^{\prime v} & \forall v \in V, i \in N_{0} \\
t_{k}^{v}-T_{\max }\left(1-\sum_{s \in P_{k}^{-}} y_{s}^{v}\right) \leq t_{k}^{\prime v} & \forall v \in V, k \in C \\
t_{k}^{v}+T_{\max }\left(1-\sum_{s \in P_{k}^{-}} y_{s}^{v}\right) \geq t_{k}^{\prime v} & \forall v \in V, k \in C \\
e+T_{\max }\left(1-\sum_{s \in P_{i}^{+} \cap P_{k}^{-}} y_{s}^{v}\right) \geq t_{k}^{\prime v}-t_{i}^{\prime v} & \forall v \in V, i \in N_{0}, k \in N_{+} \\
\left(u_{j}^{v}-u_{i}^{v}\right) \leq M\left(p_{i j}^{v}\right) & \forall v \in V, i \in N_{0}, j \in C \backslash\{i\} \\
\left(u_{j}^{v}-u_{i}^{v}\right) \geq M\left(p_{i j}^{v}-1\right)+1 & \forall v \in V, i \in N_{0}, j \in C \backslash\{i\} \\
t_{k}^{\prime v}-T_{\max }\left(3-\sum_{s \in P_{i}^{+} \cap P_{k}^{-}} y_{s}^{v}-\sum_{s \in P_{b}^{+}} y_{s}^{v}-p_{i b}^{v}\right) \leq t_{b}^{\prime v} & \forall v \in V, i \in N_{0}, k \in N_{+}, b \in C \backslash\{b\} \\
x_{i j}^{v} \in\{0,1\} & \forall v \in V,(i, j) \in A \\
y_{s}^{v} \in\{0,1\} & \forall v \in V, s \in P \\
u_{i}^{v}, t_{i}^{v}, t_{i}^{\prime v} \geq 0 & \forall v \in V, i \in N \\
p_{i j}^{v} \in\{0,1\} & \forall v \in i \in N_{0}, j \in C \backslash\{i\}
\end{array}
$$

Persamaan 1 menunjukan fungsi objektif dari permasalahan yaitu meminimumkan biaya operasional ketika mengunjungi pelanggan. Persamaan 2 memastikan setiap pelanggan hanya dikunjungi satu kali menggunakan truk ataupun drone. Persamaan 3 memastikan semua truk harus berangkat dari depot maksimal satu kali. Persamaan 4 memastikan semua truk harus kembali ke depot maskimal satu kali. Persamaan 5 memastikan tidak ada perjalanan antar depot. Persamaan 6 memastikan aliran rute. Persamaan 7 dan 8 mengeliminasi subtour pada rute truk. Persamaan 9 memastikan barang yang dibawa truk tidak melebihi kapasitas truk. Persamaan 10 dan 11 memastikan setiap titik hanya bisa satu kali menjadi titik peluncuran dan pendaratan drone. Persamaan 12 memastikan jika drone diluncurkan di titik $i \in N_{0}$ dan mendarat di titik $k \in N_{+}$maka truk harus mengunjungi titik tersebut. Persamaan 13 dan 14 memberi nilai waktu awal untuk truk dan drone. Persamaan 15 dan 16 memastikan waktu truk dan drone kembali ke depot tidak melebihi $T_{\max }$. Persamaan waktu 17 untuk truk mendefiniskan waktu truk tiba di lokasi ketika terdapat perjalanan drone diantaranya. Persamaan waktu 18 dan 19 untuk drone mendefinisikan waktu drone tiba di lokasi pelanggan bedasarkan lokasi truk. Persamaan 18 memastikan jika drone diluncurkan dari lokasi $i \in N_{0}$ ke pelanggan $j \in C^{\prime}$, maka waktu kedatangan drone di pelanggan $j$ harus lebih besar dari waktu kedatangan truk di lokasi $i$ ditambah waktu perjalanan drone dan waktu untuk peluncuran drone. Persamaan 19 memastikan jika drone selesai melayani pelanggan $j \in C^{\prime}$ dan terbang kembali ke truk di lokasi $k \in N_{+}$, maka waktu kedatangan drone di lokasi $k$ harus lebih besar dari Pengembangan Algoritma Particle Swarm Optimization dan Simulated Annealiang untuk Menyelesaikan Vehicle Routing Problem with Drone / Hasan Aji Prawira, Budi Santosa

Peer reviewed under responsibili of Universitas Muhammadiyah Sidoarjo.

(C) 2021 Universitas Muhammadiyah Sidoarjo. All Right reserved. This is an open access article under the CC BY licence (http://creativecommons.org/licences/by/4.0/) 


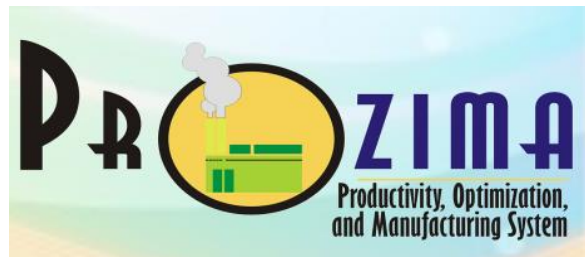

Prozima, Vol. 5, No. 1, Juni 2021, 1-12

E. ISSN. 2541-5115

Journal Homepage: http://ojs.umsida.ac.id/index.php/prozima

DOI Link: http://doi.org/ 10.21070/prozima.v5i1.1398

Article DOI: http://doi.org/ 10.21070/prozima.v5i1.1398

waktu kedatangan drone di lokasi $j$ ditambah waktu perjalanan drone, waktu melayani pelanggan, dan waktu pemulihan drone. Persamaan 20 sampai 23 memastikan sinkronisasi waktu truk dan drone. Persamaan 24 memastikan waktu terbang drone tidak melebihi batas waktu terbang drone. Pada persamaan 25 dan 26 variabel biner $p_{i j}^{v}$ didefinisikan untuk menentukan urutan rute truk, menunjukan apakah suatu pelanggan dikunjungi sebelum pelanggan lainnya. Persamaan 27 memastikan tidak ada peluncuran drone baru ketika drone sedang terbang. Persamaan 28 sampai 31 menunjukan bentuk variabel.

\section{B. Pengambangan Algoritma Particle Swarm Optimization}

Particle Swarm Optimization (PSO) merupakan salah satu metode metaheuristik atau teknik optimasi global. PSO pertama kali diperkenalkan oleh [18]. Algoritma PSO meniru perilaku dari sekumpulan organisme contohnya segerombolan ikan ataupun burung. PSO merupakan salah satu teknik metaheuristik berdasarkan populasi. PSO telah diimplementasikan untuk menyelesaikan permasalahan-permasalahan sulit dan dapat menghasilkan solusi yang kompetitif [15]. Algoritma PSO dikembangkan untuk menyelesaiakan VRPD dengan menggabungkannya dengan algoritma Route Drone. Algoritma Route Drone membantu untuk merubah vektor posisi PSO yang berbentuk vektor kontinyu menjadi rute kendaraan VRPD. Berikut ini merupakan langkahlangkah algoritma PSO yang telah dikembangkan untuk menyelesaiakan VRPD. Pertama, penentuan data permasalahan. Data permasalahan yang digunakan pada algoritma ini adalah node depot dan pelanggan, demand setiap pelanggan, kapasitas kendaraan, jumlah kendaraan, dan rute truk dari solusi VRP. Selanjutnya, penentuan parameter yaitu $\mathrm{N}$ merupakan jumlah individu setiap iterasi. It_max merupakan maksimum iterasi yang dilakukan. $c_{p}$ merupakan parameter bobot perubahan kecepatan bedasarakan pbest. $c_{g}$ merupakan parameter bobot perubahan kecepatan bedasarakan gbest. LB merupakan batas bawah koordinat. UB merupakan batas atas koordinat. Selanjutnya perhitungan matriks jarak. Matriks jarak berisi nilai jarak antar setiap pelanggan dan depot. Perhitungan jarak setiap pelanggan dan depot bedasarkan titik koordinat yang telah kumpulkan sebelumnya. Perhitungan dilakukan dengan menggunakan rumus jarak euclidean. Selanjutnya, inisialisasi vektor posisi, kecepatan, dan pbest awal. Inisialisasi vektor posisi awal dilakukan untuk setiap partikel $x_{i}$ dengan membangkit nilai random sejumlah $n$ pelanggan yang bisa dilayani oleh drone. Inisialisasi kecepatan awal dilakukan dengan memberi angka nol dengan panjang vektor yang sama dengan panjang vektor posisi awal untuk semua partikel $v_{i}^{1}=0$, dan pbest ditetapkan sama dengan vektor posisi awal $p_{i}^{1}=x_{i}^{1}$. Selanjutnya, pembentukan rute drone. Pembentukan rute drone dilakukan bedasarkan pembangkitan partikel $x_{i}$ yang telah dilakukan sebelumnya. Pembentukan rute ini dilakukan dengan menggunakan algoritma Route Drone. Selanjutnya, perhitungan nilai fitness. Untuk setiap partikel $i=1 \ldots I$, evaluasi nilai fitness $\varphi\left(x_{i}^{t}\right)$ bedasarkan nilai biaya transportasi yang ditempuh dari rute drone yang terbentuk. Selanjutnya, perbarui vektor pbest. Pembaruan vektor pbest untuk setiap partikel $i=1 \ldots I$ bedasarkan persamaan berikut.

$$
p_{i}^{t}=\left\{\begin{array}{cc}
x_{i}^{t} & \text { jika } \varphi\left(x_{i}^{t}\right)<\varphi\left(p_{i}^{t}\right) \\
p_{i}^{t} & \text { sebaliknya }
\end{array}\right.
$$

Vektor pbest $p_{i}^{t}=x_{i}^{t}$ jika nilai fitness posisi partikel kurang dari nilai fitness pbest. Selanjutnya, perbarui vektor gbest. Pembaruan vektor gbest $g^{t}$ bedasarkan vektor pbest $p_{i}^{t}$ dengan nilai fitness paling kecil. Selanjutnya, perbarui kecepatan dan vektor posisi. Pembaruan kecepatan dan posisi setiap partikel $i$ bedasarkan persamaan berikut.

$$
\begin{aligned}
& v_{i}^{t+1}=v_{i}^{t}+c_{p} u\left(p_{i}^{t}-x_{i}^{t}\right)+c_{g} u\left(g^{t}-x_{i}^{t}\right) \\
& x_{i}^{t+1}=x_{i}^{t}+v_{i}^{t+1}
\end{aligned}
$$

dengan $u \sim U(0,1) . c_{p}$ dan $c_{g}$ adalah parameter bobot perubahan kecepatan yang telah ditentukan sebelumnya. $u$ adalah bilangan random dengan distribusi uniform 0 sampai 1 . Selanjutnya, pengecekan kriteria pemberhentian.

\section{Pengembangan Algoritma Particle Swarm Optimization dan Simulated Annealiang untuk Menyelesaikan Vehicle Routing Problem with Drone / Hasan Aji Prawira, Budi Santosa}

Peer reviewed under responsibili of Universitas Muhammadiyah Sidoarjo.

(C) 2021 Universitas Muhammadiyah Sidoarjo. All Right reserved. This is an open access article

under the CC BY licence (http://creativecommons.org/licences/by/4.0/ ) 


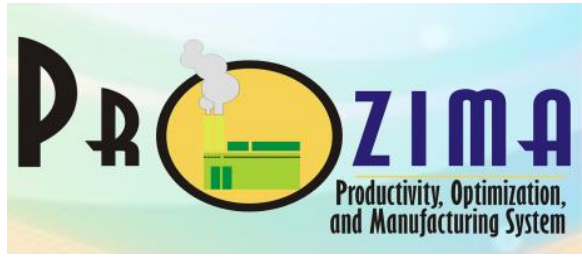

Prozima, Vol. 5, No. 1, Juni 2021, 1-12

E. ISSN. 2541-5115

Journal Homepage: http://ojs.umsida.ac.id/index.php/prozima

DOI Link: http://doi.org/ 10.21070/prozima.v5i1.1398

Article DOI: http://doi.org/ 10.21070/prozima.v5i1.1398

Pemberhentian iterasi dilakukan jika kriteria pemberhentian terpenuhi, jika belum maka kembali ke langkah pembentukan rute. Pada penelitian ini menggunakan dua kriteria pemberhentian yang digunakan yaitu standar deviasi dari nilai fitness individu telah kurang dari 1 dan jumlah iterasi. Jika kriteria pemberhentian terpenuhi dilakukan penentuan rute terbaik. Rute terbaik dibentuk dengan mengunakan algoritma Route Drone bedasarkan vektor gbest. Hasil keluaran algoritma berupa rute truk baru dan rute drone. Algoritma dijalankan untuk setiap rute truk dari solusi VRP. Solusi algoritma dari masing-masing rute truk dikumpulkan menjadi kesatuan solusi VRPD.

\section{Pengambangan Algoritma Simulated Annealing}

Simulated Annealing (SA) merupakan salah satu metode metaheuristik iteratif atau teknik optimasi global yang dikembangkan bedasarkan algoritma Monte Carlo. SA pertama kali diperkenalkan oleh [19] untuk menyelesaikan permasalahan Traveling Salesman Problem (TSP). Algoritma SA meniru cara kerja proses annealing yang biasa terjadi dalam bidang metalurgi. Algoritma SA dikembangkan untuk menyelesaiakan VRPD dengan menggabungkannya dengan algoritma Route Drone. Algoritma Route Drone membantu untuk merubah vektor posisi SA yang berbentuk vektor diskrit menjadi rute kendaraan VRPD. Berikut ini merupakan langkah-langkah algoritma SA yang telah dikembangkan untuk menyelesaiakan VRPD. Pertama, penentuan data permasalahan. Data permasalahan yang digunakan pada algoritma ini adalah node depot dan pelanggan, demand setiap pelanggan, kapasitas kendaraan, jumlah kendaraan, dan rute truk dari solusi VRP. Selanjutnya, dilakukan penentuan parameter yang akan digunakan yaitu It_max merupakan maksimum iterasi yang dilakukan, $T_{0}$ merupakan parameter temperatur awal, $\alpha$ merupakan parameter penurunan suhu, LB merupakan batas bawah koordinat, dan UB merupakan batas atas koordinat. Kemudian, dilakukan perhitungan matriks jarak. Matriks jarak berisi nilai jarak antar setiap pelanggan dan depot. Perhitungan jarak setiap pelanggan dan depot bedasarkan titik koordinat yang telah kumpulkan sebelumnya. Perhitungan dilakukan dengan menggunakan rumus jarak euclidean. Kemudian, dilakukan inisialisasi vektor solusi sementara. Inisialisasi vektor posisi awal $s$ dilakukan dengan membangkit urutan acak sejumlah pelanggan yang dapat dilayani drone. Vektor ini digunakan untuk menentukan prioritas pelanggan dalam penentuan rute drone. Kemudian, dilakukan pembentukan vektor baru. Pembentukan vektor baru dilakukan dengan cara memodifikasi solusi sementara. Pembentukan vektor baru ini dilakukan dengan tiga cara yaitu membalik (flip), menukar (swap), dan menggeser (slide). Tiga cara ini dilakukan bedasarkan teori yang ada di buku Santosa \& Ai (2017). Selanjutnya, dilakukan pembentukan rute drone. Pembentukan rute drone dilakukan bedasarkan solusi sementara $S$ dan solusi baru $s_{\text {new }}$. Pembentukan rute ini dilakukan dengan menggunakan algoritma Route Drone. Evaluasi nilai fitness $\varphi(s)$ dari solusi sementara dan $\varphi\left(s_{\text {new }}\right)$ dari solusi baru bedasarkan nilai biaya transportasi dari keseluruhan rute yang terbentuk. Selanjutnya, perbarui vektor Solusi bedasarkan temperatur. Pembaruan vektor solusi sementara bedasarkan persamaan berikut.

$$
s=\left\{\begin{array}{lc}
s_{\text {new }} & \text { jika } u<e^{\left(\frac{\varphi\left(s_{\text {new }}\right)-\varphi(s)}{T}\right)} \\
s & \text { sebaliknya }
\end{array}\right.
$$

dengan $u \sim U(0,1)$. Solusi sementara $s=s_{\text {new }}$ jika nilai acak $u$ lebih kecil dari probabilitas penerimaan $e^{\left(\frac{\varphi\left(s_{\text {new }}\right)-\varphi(s)}{T}\right)}$. Selanjutnya, perbarui vektor solusi bedasarkan fitness. Pembaruan vektor solusi sementara bedasarkan persamaan berikut.

$$
s=\left\{\begin{array}{lc}
s_{\text {new }} & \text { jika } \varphi\left(s_{\text {new }}\right)<\varphi(s) \\
s & \text { sebaliknya }
\end{array}\right.
$$

Solusi sementara $s=s_{\text {new }}$ jika nilai fitness solusi baru lebih baik dari solusi sementara. Selanjutnya, perbarui nilai parameter temperatur. Pembaruan nilai parameter temperatur bedasarkan penurunan suhu $\alpha$.

$$
T=\alpha \times T
$$

Pengembangan Algoritma Particle Swarm Optimization dan Simulated Annealiang untuk Menyelesaikan Vehicle Routing Problem with Drone / Hasan Aji Prawira, Budi Santosa

Peer reviewed under responsibili of Universitas Muhammadiyah Sidoarjo.

(C) 2021 Universitas Muhammadiyah Sidoarjo. All Right reserved. This is an open access article under the CC BY licence (http://creativecommons.org/licences/by/4.0/ ) 


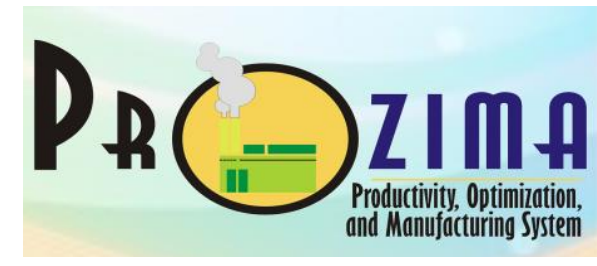

Prozima, Vol. 5, No. 1, Juni 2021, 1-12

E. ISSN. 2541-5115

Journal Homepage: http://ojs.umsida.ac.id/index.php/prozima

DOI Link: http://doi.org/ 10.21070/prozima.v5i1.1398

Article DOI: http://doi.org/ 10.21070/prozima.v5i1.1398

Selanjutnya, cek kriteria pemberhentian. Pemberhentian iterasi dilakukan jika kriteria pemberhentian terpenuhi, jika belum maka kembali ke langkah pembentukan vektor baru. Pada penelitian ini menggunakan kriteria pemberhentian yang digunakan yaitu jumlah iterasi. Jika kriteria pemberhentian terpenuhi maka dilakukan penentuan rute terbaik. Rute terbaik dibentuk dengan mengunakan algoritma Route Drone bedasarkan vektor solusi sementara. Hasil keluaran algoritma berupa rute truk baru dan rute drone. Algoritma dijalankan untuk setiap rute truk dari solusi VRP. Solusi algoritma dari masing-masing rute truk dikumpulkan menjadi kesatuan solusi VRPD.

\section{Pengembangan Algortima Route Drone}

Algoritma Route Drone dikembangkan untuk membantu algoritma SA dalam menyelesaiakan VRPD. Algoritma ini digunakan untuk mengubah vektor algoritma SA menjadi rute drone. Berikut ini merupakan garis besar tahapan algoritma Route Drone yang dikembangkan. Pertama, penentuan data masukan. Data masukan yang digunakan pada algoritma ini adalah urutan prioritas drone, rute truk, dan biaya rute. Selanjutnya, penentuan jumlah pelanggan yang dilayani drone. Jumlah pelanggan yang akan dilayani drone ditentukan bedasarkan jumlah pelanggan yang memiliki demand kurang dari kapasitas drone. Hal ini dilakukan karena tidak semua pelanggan bisa dilayani oleh drone. Penentuan jumlah pelanggan yang akan dilayani drone $\beta$ dilakukan bedasarkan persamaan berikut.

$$
\beta=\min \left(\max \left(c_{\text {low }}, \delta .|C|\right), c_{\text {lim }}\right)
$$

dengan $\delta$ merupakan rasio jumlah pelanggan yang akan dilayani oleh drone, $c_{\text {low }}$ dan $c_{\text {lim }}$ adalah batas bawah dan batas atas jumlah pelanggan yang harus dilayani oleh drone, dan $|C|$ adalah jumlah pelanggan yang memiliki demand kurang dari kapasitas drone. Selanjutnya, penghapusan pelanggan drone dari rute truk. Pelanggan yang memiliki urutan prioritas pertama sampai $\beta$ dihapus dari rute truk. Pelanggan-pelanggan ini dihapus dari rute truk karena mereka akan dimasukan ke rute drone. Selanjutnya, perhitungan biaya rute truk. Biaya rute truk dihitung kembali untuk penurunan biaya pada rute truk. Penurunan biaya ini akan menjadi constraint pada pemasukan pelanggan ke rute drone. Selanjutnya, pemasukan pelanggan ke rute drone. Pemasukan pelanggan ke rute drone dilakukan satu persatu sampai jumlah pelanggan yang telah ditentukan sebelumnya. Urutan pemasukan pelanggan dilakukan bedasarkan urutan prioritas pelanggan. Pemasukan pelanggan ini menggunakan algoritma cheapest insertion. Setiap pemasukan pelanggan ke rute drone dilakukan pengecekan terhadap constraint. Selnajutnya, pengecekan constraint. Constraint yang digunakan pada algoritma ini adalah total biaya rute drone harus lebih kecil dari penurunan biaya rute truk, waktu rute drone untuk setiap pelanggan harus lebih kecil dari pada waktu ketahanan drone, drone hanya bisa melayani satu pelanggan setiap rute. Jika constraint terpenuhi maka dilakukan perhitungan total biaya rute. Total biaya dihitung bedasarkan total biaya rute truk dan total biaya rute drone.

\section{HASIL DAN PEMBAHASAN}

\section{A. Desain Eksperimen}

Data yang digunakan bedasarkan skenario yang ada di dalam penelitian [8]. Dalam penelitian [8] data kasus yang terdiri dari data jumlah pelanggan, jumlah barang, koordinat pelanggan, biaya operasional truk, biaya operasional drone, kecepatan truk, kecepatan drone, waktu peluncuran, dan waktu pendaratan drone yang dijelaskan pada Tabel 1.

Tabel 1. Parameter Data Uji

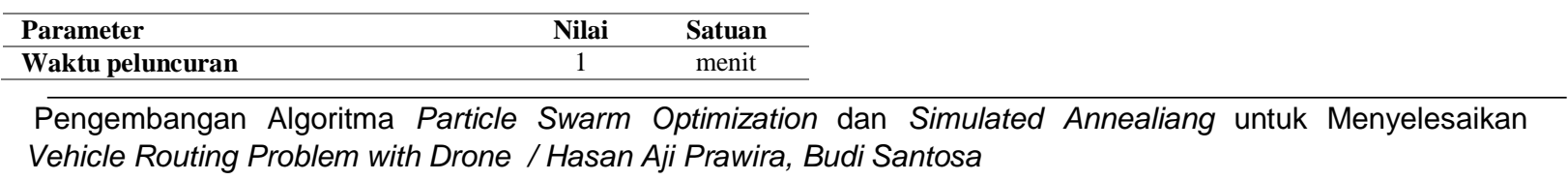

Peer reviewed under responsibili of Universitas Muhammadiyah Sidoarjo.

(C) 2021 Universitas Muhammadiyah Sidoarjo. All Right reserved. This is an open access article

under the CC BY licence (http://creativecommons.org/licences/by/4.0/ ) 


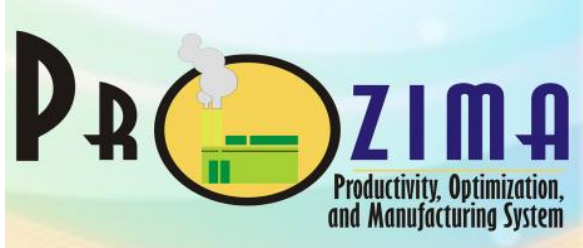

Prozima, Vol. 5, No. 1, Juni 2021, 1-12

E. ISSN. 2541-5115

Journal Homepage: http://ojs.umsida.ac.id/index.php/prozima

DOI Link: http://doi.org/ 10.21070/prozima.v5i1.1398

Article DOI: http://doi.org/ 10.21070/prozima.v5i1.1398

\begin{tabular}{lcc}
\hline Waktu pendaratan & 1 & menit \\
\hline Kecepatan truk & 35 & $\mathrm{mil} / \mathrm{jam}$ \\
\hline Kecepatan drone & 50 & $\mathrm{mil} / \mathrm{jam}$ \\
\hline Batas waktu terbang drone & 30 & $\mathrm{menit}$ \\
\hline Kapasitas truk & 1300 & $\mathrm{~kg}$ \\
\hline Kapasitas drone & 5 & $\mathrm{~kg}$ \\
\hline Biaya operasional truk & 0.1274 & $\mathrm{euro} / \mathrm{km}$ \\
\hline Biaya operasional drone & 0.0127 & euro $/ \mathrm{km}$ \\
\hline
\end{tabular}

Penelitian ini mengevaluasi kinerja kedua metode PSO dan SA dengan 32 set data masalah acak. Data skenario mempunyai skala yang berbeda, dari skala kecil hingga skala besar, dengan 6 sampai 100 pelanggan. Setiap skenario data memiliki tingkat kerumitan yang berbeda-beda. Perbedaan tingkat kerumitan untuk setiap data skenario digunakan untuk menganalisis sensitivitas dari algoritma yang digunakan. Pengujian algoritma dengan skenario data diatas dilakukan dengan parameter yang telah dijelaskan sebelumnya. Stopping criteria yang digunakan adalah standar deviasi kurang dari $10^{-5}$ dan jumlah maksimum iterasi. Parameter yang digunakan untuk algoritma PSO adalah $\mathrm{N}=50$, It_max $=100, c_{p}=0.8$, dan $c_{g}=0.8$. Parameter yang digunakan pada algoritma SA adalah It_max $=5000, \mathrm{k}=1$, dan $\alpha=0.9$. Hasil eksperimen kedua algoritma dibandingkan dengan solusi best known dari penelitian Sacramento dkk. (2019).

\section{B. Analisis Hasil Komputasi}

Algoritma PSO dan SA dapat digunakan untuk menyelesaikan Vehicle Routing Problem with Drone dengan cara mengkombinasikannya dengan algoritma Route Drone. Algoritma Route Drone digunakan untuk mengubah struktur solusi PSO dan SA menjadi solusi Vehicle Routing Problem with Drone. Dari hasil eksperimen pada 6 skenario jumlah pelanggan, algoritma PSO dan algoritma SA dapat menghasilkan solusi yang mendekati solusi optimal. Hal tersebut dapat dilihat dari nilai gap dan nilai Relative Percentage Deviation antara hasil dari eksperimen dan hasil dari referensi pada Tabel 2.

Tabel 2. Nilai Gap dan RPD Semua Skenario

\begin{tabular}{|c|c|c|c|c|c|c|c|c|c|}
\hline \multirow[t]{2}{*}{ Skenario } & \multicolumn{2}{|c|}{ PSO-Referensi } & \multicolumn{2}{|c|}{ SA-Referensi } & \multirow[t]{2}{*}{ Skenario } & \multicolumn{2}{|c|}{ PSO-Referensi } & \multicolumn{2}{|c|}{ SA-Referensi } \\
\hline & RPD & Gap & RPD & Gap & & RPD & Gap & RPD & Gap \\
\hline 6.5.1 & $0.00 \%$ & 0.00 & $0.00 \%$ & 0.00 & 20.5 .1 & $-1.02 \%$ & -0.02 & $-1.99 \%$ & -0.04 \\
\hline 6.5 .2 & $0.00 \%$ & 0.00 & $0.00 \%$ & 0.00 & 20.5 .2 & $-4.22 \%$ & -0.08 & $-4.22 \%$ & -0.08 \\
\hline 6.5 .3 & $-11.78 \%$ & -0.14 & $-11.78 \%$ & -0.14 & 20.5 .3 & $0.06 \%$ & 0.00 & $0.00 \%$ & 0.00 \\
\hline 6.5.4 & $0.11 \%$ & 0.00 & $0.00 \%$ & 0.00 & 20.5 .4 & $0.00 \%$ & 0.00 & $0.00 \%$ & 0.00 \\
\hline 10.5.1 & $0.00 \%$ & 0.00 & $0.00 \%$ & 0.00 & 50.10 .1 & $-4.15 \%$ & -0.24 & $-6.61 \%$ & -0.39 \\
\hline 10.5.2 & $0.00 \%$ & 0.00 & $0.00 \%$ & 0.00 & 50.10 .2 & $3.28 \%$ & 0.18 & $0.00 \%$ & 0.00 \\
\hline 10.5 .3 & $-2.24 \%$ & -0.03 & $-2.24 \%$ & -0.03 & 50.10 .3 & $4.16 \%$ & 0.23 & $-0.01 \%$ & 0.00 \\
\hline 10.5 .4 & $0.00 \%$ & 0.00 & $0.00 \%$ & 0.00 & 50.10 .4 & $10.64 \%$ & 0.55 & $-0.66 \%$ & -0.03 \\
\hline 12.5.1 & $0.00 \%$ & 0.00 & $0.00 \%$ & 0.00 & 100.10 .1 & $14.14 \%$ & 0.97 & $1.33 \%$ & 0.09 \\
\hline 12.5.2 & $0.00 \%$ & 0.00 & $0.00 \%$ & 0.00 & 100.10 .2 & $8.72 \%$ & 0.66 & $0.86 \%$ & 0.07 \\
\hline 12.5 .3 & $0.00 \%$ & 0.00 & $0.00 \%$ & 0.00 & 100.10 .3 & $12.27 \%$ & 0.88 & $0.69 \%$ & 0.05 \\
\hline 12.5.4 & $0.00 \%$ & 0.00 & $0.00 \%$ & 0.00 & 100.10 .4 & $5.80 \%$ & 0.43 & $-0.25 \%$ & -0.02 \\
\hline \multicolumn{6}{|c|}{ Rata-rata } & $-1.16 \%$ & -0.01 & $-1.17 \%$ & -0.01 \\
\hline
\end{tabular}

Pada Tabel 2 dapat dilihat bahwa rata-rata RPD untuk algoritma PSO dan SA dibandingkan nilai referensi memiliki nilai dibawah 5\% yaitu sebesar $1,49 \%$ dan $-1.04 \%$. Hal ini menunjukan bahwa algoritma PSO dan SA dapat menghasilkan solusi yang mendekati solusi dari referensi. Pada skenario 6 pelanggan algoritma PSO dan SA mampu menghasilkan solusi yang sama dan lebih baik dari referensi. Hal ini dapat dilihat pada skenario 6.5.1, 6.5.2, dan 6.5.4 kedua algoritma memiliki RPD yang bernilai 0,00\% serta pada skenario 6.5.3 kedua algoritma memiliki nilai RPD negatif yaitu $-11,78 \%$. Nilai RPD negatif menunjukan bahwa algoritma yang dikembangkan mampu menghasilkan solusi yang lebih baik dari referensi. Bedasarkan hasil dapat disimpulkan bahwa algoritma PSO dan SA yang dikembangkan dapat menemukan solusi optimal apabila jumlah pelanggan sedikit. Sama halnya pada skenario 10 dan 12 pelanggan, algoritma PSO dan SA yang dikembangkan dapat

Pengembangan Algoritma Particle Swarm Optimization dan Simulated Annealiang untuk Menyelesaikan Vehicle Routing Problem with Drone / Hasan Aji Prawira, Budi Santosa

Peer reviewed under responsibili of Universitas Muhammadiyah Sidoarjo.

(C) 2021 Universitas Muhammadiyah Sidoarjo. All Right reserved. This is an open access article

under the CC BY licence (http://creativecommons.org/licences/by/4.0/ ) 


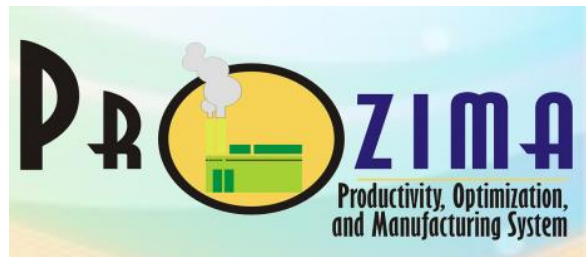

Prozima, Vol. 5, No. 1, Juni 2021, 1-12

E. ISSN. 2541-5115

Journal Homepage: http://ojs.umsida.ac.id/index.php/prozima

DOI Link: http://doi.org/ 10.21070/prozima.v5i1.1398

Article DOI: http://doi.org/ 10.21070/prozima.v5i1.1398

menghasilkan solusi yang sama bahkan dapat menghasilkan solusi yang lebih baik dari pada referensi pada beberapa skenario. Tetapi pada skenario 20 pelanggan yaitu pada skenario 20.5.3, algoritma PSO yang dikembangkan hanya dapat menghasilkan solusi yang mendekati solusi referensi. Sedangkan untuk algoritma SA masih mampu menghasilkan solusi yang sama dan lebih baik dari referensi. Pada skenario 50 pelanggan algoritma PSO hanya dapat menghasilkan solusi yang mendekati solusi referensi kecuali pada skenario 50.10.1 algoritma PSO mampu menghasilkan solusi yang lebih baik dari referensi. Sedangkan untuk algoritma SA masih mampu menghasilkan solusi yang sama dan lebih baik dari referensi. Pada skenario 100 pelanggan, kedua algoritma hanya dapat menghasilkan solusi yang mendekati solusi referensi kecuali pada skenario 100.10.4 algoritma SA mampu menghasilkan solusi yang lebih baik dari referensi. Algoritma PSO dan SA tidak dapat menghasilkan solusi yang sama dengan referensi dikarenakan dalam pencarian solusi ada kemungkinan tejebak pada solusi lokal optimal.

Algoritma PSO dan SA yang dikembangkan menggunakan metode heuristik yang dikembangkan sendiri oleh peneliti yaitu algoritma Route Drone. Metode ini juga merupakan metode local search sehingga solusi yang dihasilkan merupakan solusi lokal optimal. Pada algoritma Route Drone ini tidak mengakomodasi pembuatan rute baru oleh truk sehingga rute drone hanya berpaku pada rute yang dihasilkan dari penyelesaian VRP. Hal tersebut menyebabkan terdapat potensi rute drone yang tidak bisa dilakukan. Sehingga pembentukan rute drone sangat bergantung dari rute kendaraan awal yang dihasilkan dari penyelesaian VRP. Oleh karena itu penggunaan metode heuristik pada pembentukan rute drone berpengaruh pada kemungkinan solusi yang dihasilkan oleh algoritma PSO dan SA yang dikembangkan terjebak pada solusi lokal optimal.

Pada Tabel 2 dapat dilihat bahwa nilai RPD SA-Referensi memiliki nilai yang lebih kecil dari pada nilai RPD PSO-Referensi. Hal tersebut menunjukan bahwa solusi yang dihasilkan oleh algoritma SA lebih baik dari pada solusi yang dihasilkan oleh algoritma PSO. Hal tersebut dapat disebabkan kurang tepatnya pembuatan struktur solusi algoritma karena ketidaksesuaian algoritma dengan permasalahan. Permasalahan VRPD merupakan permasalahan kombinatorial yang berupa urutan pelanggan. Algoritma PSO merupakan algoritma yang pertama kali dikembangkan untuk menyelesaikan permasalahan kontinyu. Tetapi algoritma PSO telah banyak digunakan untuk menyelesaikan permasalahan kombinatorial dengan mengubah struktur nilai kontinyu yang dihasilkan algoritma PSO menjadi prioritas urutan. Pengubahan struktur ini tidak lebih bagus dalam menyelesaikan permasalahan kombinatorial jika dibandingkan algoritma SA yang pada dasarnya dikembangkan untuk menyelesaikan permasalahan kombinatorial ataupun kontinyu. Selain pengaruh ketidaksesuaian algoritma, perbedaan hasil algoritma PSO dan SA juga disebabkan oleh adanya langkah-langkah khusus untuk keluar dari lokal optimal pada algoritma SA. Pada algoritma SA tedapat suatu langkah penerimaan individu bedasarkan peluang penerimaan meskipun solusi individu tersebut lebih buruk dari individu sebelumnya. Peluang penerimaan ini dipengaruhi oleh parameter temperatur pada algoritma SA. Semakin tinggi temperatur iterasi maka semakin besar peluang penerimaan. Langkah tersebut dilakukan dengan harapan penerimaan individu tersebut dapat menuju individu yang lebih baik pada iterasi selanjutnya. Langkah tersebut membuat arah pergerakan individu pada algoritma SA dapat keluar dari lokal optimal dimana hal tersebut tidak dilakukan pada algoritma PSO.

\section{SIMPULAN}

Algoritma PSO dan SA berhasil dikembangkan untuk menyelesaikan Vehicle Routing Problem with Drone dengan cara mengkombinasikan algoritma PSO dan SA dengan algoritma Route Drone untuk penentuan rute drone. Algoritma PSO dapat menghasilkan solusi yang lebih baik atau sama dengan solusi referensi pada skenario berukuran 6 - 12 pelanggan tetapi pada skenario 50 - 100 pelanggan algoritma PSO belum mampu menghasilkan solusi yang lebih baik atau sama dengan solusi referensi karena ada kemungkinan terjebak solusi lokal optimal. Algoritma SA dapat menghasilkan solusi yang lebih baik atau sama dengan solusi referensi pada skenario berukuran 6 - 50 pelanggan tetapi pada skenario 100 pelanggan terdapat beberapa skenario yang algoritma SA belum mampu menghasilkan solusi yang lebih baik atau sama dengan solusi referensi. Bedasarkan

Pengembangan Algoritma Particle Swarm Optimization dan Simulated Annealiang untuk Menyelesaikan Vehicle Routing Problem with Drone / Hasan Aji Prawira, Budi Santosa

Peer reviewed under responsibili of Universitas Muhammadiyah Sidoarjo.

(C) 2021 Universitas Muhammadiyah Sidoarjo. All Right reserved. This is an open access article

under the CC BY licence (http://creativecommons.org/licences/by/4.0/ ) 


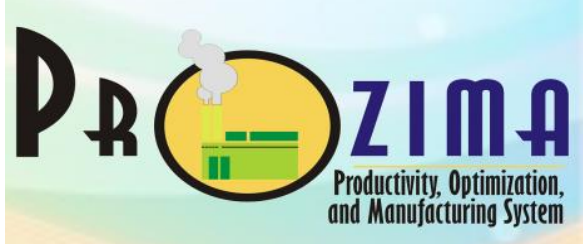

Prozima, Vol. 5, No. 1, Juni 2021, 1-12

E. ISSN. 2541-5115

Journal Homepage: http://ojs.umsida.ac.id/index.php/prozima

DOI Link: http://doi.org/ 10.21070/prozima.v5i1.1398

Article DOI: http://doi.org/ 10.21070/prozima.v5i1.1398

nilai Relavite Percentage Deviation (RPD) dari hasil eksperimen pada 6 skenario jumah pelanggan dapat disimpulkan bahwa algoritma SA menghasilkan solusi yang lebih baik daripada algoritma PSO.

\section{DAFTAR PUSTAKA}

[1] Rao, B., Gopi, A. G., \& Maione, R. (2016). The societal impact of commercial drones. Technology in Society, 45, 83-90. https://doi.org/10.1016/j.techsoc.2016.02.009

[2] Wohlsen, M. (2014). The Next Big Thing You Missed: Amazon's Delivery Drones Could Work-They Just Need Trucks. Retrieved from https://www.wired.com/2014/06/the-next-big-thing-you-missed-deliverydrones-launched-from-trucks-are-the-future-of-shipping/

[3] Rose, C. (2013). Amazon's Jeff Bezos looks to the future. Retrieved from https://www.cbsnews.com/news/amazons-jeff-bezos-looks-to-the-future/

[4] Bryan, V. (2014). Drone delivery: DHL "parcelcopter" flies to German isle. Retrieved from https://www.reuters.com/article/us-deutsche-post-drones/drone-delivery-dhl-parcelcopter-flies-to-germanisle-idUSKCNOHJ1ED20140924

[5] Mulia, K. (2019). JD warms Indonesia up to drone deliveries with first government-endorsed test flight. Retrieved from https://kr-asia.com/jd-warms-indonesia-up-to-drone-deliveries-with-first-governmentendorsed-test-flight

[6] Trop, J. (2016). Drone Delivery is About to Disrupt the Trucking Industry. Retrieved from https://www.trucks.com/2016/06/21/drone-delivery-reshape-trucking/

[7] Toth, P., \& Vigo, D. (2002). Vehicle Routing: Problems, Methods, and Applications (2nd ed.). SIAM Society for Industrial and Applied Mathematics.

[8] Sacramento, D., Pisinger, D., \& Ropke, S. (2019). An adaptive large neighborhood search metaheuristic for the vehicle routing problem with drones. Transportation Research Part C: Emerging Technologies, 102(March), 289-315. https://doi.org/10.1016/j.trc.2019.02.018

[9] Murray, C. C., \& Chu, A. G. (2015). The flying sidekick traveling salesman problem: Optimization of droneassisted parcel delivery. Transportation Research Part C: Emerging Technologies, 54, 86-109. https://doi.org/10.1016/j.trc.2015.03.005

[10] Ponza, A. (2016). Optimization of Drone-Assisted Parcel Delivery. 80.

[11] Ha, Q. M., Deville, Y., Pham, Q. D., \& Hà, M. H. (2018). On the min-cost Traveling Salesman Problem with Drone. Transportation Research Part C: Emerging Technologies, 86(May 2016), 597-621. https://doi.org/10.1016/j.trc.2017.11.015

[12] Wang, Z., \& Sheu, J. B. (2019). Vehicle routing problem with drones. Transportation Research Part B: Methodological, 122, 350-364. https://doi.org/10.1016/j.trb.2019.03.005

[13] Ham, A. M. (2018). Integrated scheduling of m-truck, m-drone, and m-depot constrained by time-window, drop-pickup, and m-visit using constraint programming. Transportation Research Part C: Emerging Technologies, 91(March), 1-14. https://doi.org/10.1016/j.trc.2018.03.025

[14] Santosa, B., \& Ai, T. J. (2017). Pengantar Metaheuristik - Implementasi dengan Matlab (1st ed.). Surabaya: ITS Tekno Sains.

[15] Poli, R., Kennedy, J., \& Blackwell, T. (2007). Particle swarm optimization: An overview. Swarm Intelligence, 1(1), 33-57. https://doi.org/10.1007/s11721-007-0002-0

[16] Ai, T. J., \& Kachitvichyanukul, V. (2009). Particle swarm optimization and two solution representations for solving the capacitated vehicle routing problem. Computers and Industrial Engineering, 56(1), 380-387. https://doi.org/10.1016/j.cie.2008.06.012

[17] Schermer, D., Moeini, M., \& Wendt, O. (2018). Algorithms for Solving the Vehicle Routing Problem with Drones. Lecture Notes in Computer Science (Including Subseries Lecture Notes in Artificial Intelligence and Lecture Notes in Bioinformatics), 10751 LNAI, 352-361. https://doi.org/10.1007/978-3-319-754178_33

Pengembangan Algoritma Particle Swarm Optimization dan Simulated Annealiang untuk Menyelesaikan Vehicle Routing Problem with Drone / Hasan Aji Prawira, Budi Santosa

Peer reviewed under responsibili of Universitas Muhammadiyah Sidoarjo.

(C) 2021 Universitas Muhammadiyah Sidoarjo. All Right reserved. This is an open access article

under the CC BY licence (http://creativecommons.org/licences/by/4.0/ ) 
[18] Kennedy, J., \& Eberhart, R. (1995). Particle Swarm Optimization. Proceedings of the IEEE International Conference on Neural Networks, 4, 1942-1948. https://doi.org/10.1109/TST.2016.7442504

[19] Kirkpatrick, S., Gelatt, C. D., \& Vecchi, M. P. (1983). Optimization by simulated annealing. Science, 220(4598), 671-680. https://doi.org/10.1126/science.220.4598.671 